\title{
UPAYA PENINGKATAN KUALITAS TANAMAN KEDELAI (Glycine max L. Merill) MELALUI PEMANFAATAN BIOTEKNOLOGI DALAM MENGATASI KELANGKAAN PANGAN
}

\section{(Efforts to Improve Quality of Soybean Plant (Glycine max L. Merill) Through the use of Biotechnology in Overcoming Food Scarcity)}

\author{
${ }^{1)}$ Edi Tando dan ${ }^{2)}$ Muh. Afif Juradi \\ ${ }^{1)}$ Balai Pengkajian Teknologi Pertanian Sulawesi Tenggara \\ ${ }^{2)}$ Balai Pengkajian Teknologi Pertanian Sulawesi Tengah
}

\begin{abstract}
Population growth the rapidly is currently a major challenges to business world food supply. The development of biotechnology begins with technology genetically engineered has accelerated. Products of biotechnology plants resembling plants provenance, but having the characteristics of certain that causes those plants better. Plant products of biotechnology which has been approved for food as having the nature of : 1) resistance to pests and disease, 2) resistance to herbicide, 3) nutrition changes and 4) content increased save resources. The purpose of drafting this paper is to provide information about improving the quality of the soybean plant (Glycine max l.Merill) through the use of biotechnology in addressing scarcity of food.The genetically engineered in plants soybean, includes extraction process dna ( modification ctab) method of the leaves of plants tangential and soybean R1 R2. Fragments of dna the genome of $0.8 \mathrm{~kb}$ involved in tolerant asam-al at $\mathrm{b}$. Japonicum 38 has successfully isolated using inverse PCR technique, Fragments of dna has been successfully diklon into plasmid vector pgemt-easy ( $3 \mathrm{~kb})$ produce recombinant plasmid pgemt-38 a 3.8 family planning. Ttransfer genes pinii in plants soy has successfully done through a. Tumefaciens with one of his event at1 ( tidar) showing the pcr positive on pinii genes. Protocol best for soybean through the transformation of a. Tumefaciens is using eksplan cotyledon young with the density of bacteria 1 x 108 / cell mls inoculation / long 90 minutes and long kokultivasi 5 days. The soybean plant ATIR1 ( tidar) transformation through a result. Tumefaciens a little more resistant to pest borer rather than the pods the soybean plant nontransgenik (control).
\end{abstract}

Keyword : quality; biotechnology; soybean.

\section{PENDAHULUAN}

TanamanKedelai (Glycine max L. Merill) di Indonesia ialahkomoditas strategis ketiga setelah padi dan jagung, karena setiap hari dikonsumsi hampir sebagian masyarakat dengan tingkat konsumsi rata - rata 8,12 kg/kapita/tahun (Sudaryanto dan Swastika, 2007). Sementara, kebutuhan kedelai akan terus meningkat sejalan dengan bertambahnya jumlah penduduk. Hal ini tercermin dari permintaan kedelai dalam sepuluh tahun terakhir yang terus meningkat, jauh melampaui produksi dalam negeri. Oleh karena itu upaya peningkatan produksi harus diupayakan melalui perluasan areal tanam (Harsono, 2008).

Pertumbuhan penduduk yang semakin pesat saat ini menjadi tantangan besar bagi usaha penyediaan pangan dunia. Badan pangan dunia atau FAO, memperkirakan akan terjadi kelangkaan 
pangan dunia pada tahun 2050. Sektor pertanian sebagai penyedia pangan dituntut lebih produktif dalam mengimbang itingginya kebutuhan pangan dunia yang meningkat hingga $70 \%$. Suryanegara (2011) menyatakan bahwa salah satu upaya untuk menjawab tantangan tersebut, antara lain melalui penerapan bioteknologi melalui rekayasa genetika.

\section{Perkembangan bioteknologi} diawali dengan teknologi rekayasa genetika menjadi semakin cepat. Dalam dogma sentral atau pemahaman dasar ilmu biologi diketahui bahwa cetak biru kehidupan DNA menyimpan informasi yang pemanfaatannya dilakukan melalui perubahan informasi ke materi baru yaitu RNA. Proses ini disebut transformasi. Selanjutnya RNA juga dirubah informasinya ke dalam materi akhir yaitu protein dalam proses translasi. Dari alur informasi dalam dogma sentral itu bisa dipahami bahwa rekayasa DNA/genetika membawa implikasi pada perubahan RNA sebagai materi pertengahan maupun kepada protein sebagai produk akhir.

Rekayasa genetika merupakan usaha manusia dengan sengaja mengubah, memodifikasi dan atau menambahkan susunan suatu gen dengan material baru kedalam suatu organisme untuk mendapatkan generasi sesuai tujuan yang diinginkan. Rekayasa genetika merupakan solusi untuk mengatasi kelangkaan pangan dengan ditemukannya teknologi tanaman transgenic atau Genetically Modified Organism (GMO) (Karmana, 2009).

Tanaman produk bioteknologi telah banyak diperdagangkan di pasar. Tanaman hasil rekayasa genetika tersebut menyerupai tanaman asalnya, tetapi memiliki sifat - sifat tertentu yang menyebabkan tanaman tersebut lebih baik. Tanaman produk bioteknologi yang telah disetujui untuk pangan merupakan tanaman yang direkayasa untuk memiliki sifat seperti : (1) ketahanan terhadap hama dan penyakit, (2) ketahanan terhadap herbisida, (3) perubahan kandungan nutrisi dan (4) peningkatan dayasimpan (Manuhara, 2006)

Tujuan penyusunan makalah ini adalah untuk memberikan informasi tentang upaya peningkatan kualitas tanaman kedelai (Glycine max L. Merill) melalui pemanfaatan bioteknologi dalam mengatasi kelangkaan pangan. 


\section{PEMBAHASAN}

\section{Peranan Bioteknologi}

Bioteknologi didefinisikan sebagai penerapan prinsip - prinsip biologi, biokimia dan rekayasa dalam pengolahan bahan dengan memanfaatkan agensia jasad hidup dan komponen komponennya untuk menghasilkan barang dan jasa. Bioteknologi selalu berkaitan dengan reaksi - reaksi biologis yang dilakukan oleh jasad hidup sebagai suatu individu atau komponen - komponenya yang dapat berupa organel, sel atau jaringan atau bahkan molekul - molekul tertentu, misalnya DNA, RNA, protein atau enzim. Ilmu yang mendasari bioteknologi ialah mikrobiologi, genetika, biokimia, biologi molekuler, ilmu pangan, rekayasa kimia, rekayasa mekanik, teknologi pangan, elektronik dan computer (Yuwono, 2012)

\section{Melaluiupayamemanfaatkan}

kemajuan bioteknologi seperti rekayasa genetik, gen-gen yang bermanfaat dari sumber yang berbeda seperti bakteri atau spesies tanaman lain yang sama sekali tidak memiliki kekerabatan dapat diisolasi dan gen tersebut dapat dimasukkan ke dalam tanaman yang akan diperbaiki melalui metode transfer genetik (Seraj,
2001).

Selanjutnya pemanfaatan teknologi biologi molekuler, gen yang diinginkan dapat dipotong dari suatu genom tanaman dan disambung ke dalam genom lain melalui suatu eksperimen yang unik, tanpa memindahkan gen-gen yang tidak diinginkan selama proses (Fernandes dan Filho, 1993).

Tanaman transgenik merupakan suatutanaman yang memiliki gen atau telah disisipi gen dari organisme lain, dan dapat pula disebut sebagai Genetically Modified Organism (organisme yang termodifikasi secara genetik). Penyisipan gen ini umumnyalebih diarahkan ke tanaman pangan untuk menciptakan kualitas pangan yang lebih baik daripada sebelumnya.

\section{Rekayasa Genetik pada Tanaman Kedelai}

Salah satu jenis tanaman produk bioteknologi ialah kedelai. Kedelai merupakan tanaman penghasil minyak yang mempunyai nilai ekonomi tinggi. Bijinya mengandung asam amino esensial lebih tinggi di banding daging, sehingga merupakan tanaman pangan yang sangat penting saat ini.

Rekayasa genetika pada tanaman mencakup beberapa tahapan,yaitu : 1) Ekstraksi DNA, 2) Kloning gen, 3) 
Desain gen, 4) Transformasi genetika dan 5) Pemuliaan tanaman di lapangan.

Proses rekayasa genetika pada tanaman kedelai (Glycine max L. Merill), dalam mengatasi kelangkaan pangan saat ini mencakup beberapa tahapan atau proses, antara lain :

\section{Ekstraksi DNA}

Ekstraksi DNA atau isolasi DNA target merupakan prosedur umum dalammemisahkan dan mengumpulkan DNA untuk analisis rekayasa genetika, forensik, bioinformatika, komputasi, analisis asal-usul dan antropologi. Prinsip dasar Ekstraksi DNA adalah mengeluarkan DNA dari sel.

Hasil penelitian Hadiarto et al ., (2002) menunjukkan bahwa proses transfer suatu gen asing ke dalam genom suatu tanaman target dimulai dengan pemasukan gen asing ke dalam sitoplasma sel tanaman target. Selanjutnya gen ini akan masuk ke dalam inti sel tanaman melalui pori - pori membran inti sel. Apabila gen asing tersebut berhasil masuk atau menyisip ke dalam kromosom tanaman target dan berintegrasi dengan baik (berada pada bagian yang aktif ditranskripsi), maka gen itu akan dapat diekspresikan oleh tanaman transforman.
Suatucontoh proses ekstraksi DNA (modifikasi metode CTAB) yaitu DNA diekstrak dari daun tanaman kedelai transgenik R1 dan R2 yang telah ditanam di rumah kaca. Ekstraksi DNA dilakukan dengan cara menggerus kurang lebih 0,5-2 $\mathrm{g}$ daun yang telah disimpan dalam ruang gelap bersuhu $-20^{\circ} \mathrm{C}$ dengan nitrogen cair hingga menjadi serbuk halus. Serbuk daun ter-sebut dipindahkan ke dalam tabung corning dan ditambah dengan bufer ekstraksi $1 \mathrm{M}$ Tris $\mathrm{HCl}(\mathrm{pH}$ 7,5); 0,5 M EDTA (pH 8); 5 M NaCl; 1\% CTAB; 140 $\mathrm{mM}$ Na-bisulfite. Campuran tersebut kemudian digoyang perlahan dan disimpan pada inkubator $65^{\circ} \mathrm{C}$, selama 15 menit. Setelah didinginkan pada suhu ruang selama 4 - 6 menit, ekstraksi kemudian dilanjutkan dengan menambahkan $6 \mathrm{ml}$ chloroform : isoamilalkohol (24: 1). Campuran tersebut digoyang kembali selama 20 menit. Setelah supernatan akhir dipisahkan, campuran kemudian ditambahkan 2 vol. 95\% EtOH dingin. Setelah dicampur merata, kemudian pelet DNA diambil dengan pipet pasteur dan dipindahkan ke dalam eppendorf 1,5 ml. Endapan DNA dicuci dengan alkohol $70 \%$ dingin (2 kali), kemudian dikeringkan dengan mesin evaporator VWR 1410. Endapan DNA 
kemudian dilarutkan dalam 1x TE bufer (10 mM Tris $\mathrm{HCl} \mathrm{pH}$ 7,5; 0,1 mM EDTA $\mathrm{pH}$ 8). Purifikasi DNA pelet yang diperoleh, dilakukan dengan menambahkan $3 \mathrm{ml}$ RNase dan $3 \mathrm{ml}$ proteinase $\mathrm{K}(1 \mathrm{mg} / \mathrm{ml}) 37^{\circ} \mathrm{C}, 60$ menit. Kemudian tambahkan $1 / 10$ vol. 3M NaOAc. Tambahkan 2 vol. EtOH absolut, dicampur merata. Pelet DNA dipindahkan ke eppendory baru, kemudian dicuci dengan $\mathrm{EtOH} 70 \%$ (v/v), selanjutnya dikeringkan dan dilarutkan dalam TE (1 kali) dan disimpan dalam suhu $-20^{\circ} \mathrm{C}$.

DNA tanaman sampel yang telah dimurnikan digunakan untuk analisisPCR. Volume yang digunakan dalam PCR untuk 1 kali reaksi adalah $25 \mathrm{ml}$ dengan komposisi bahan 1 kali bufer PCR yang mengandung $\mathrm{MgCl} 20,25 \mathrm{mM} ; 200 \mathrm{mM}$ dNTP; $100 \mathrm{nM}$ primer forward dan reverse pinII; $1,5 \mathrm{u} / \mathrm{ml}$ enzim Taq DNA polymerase (Promega, Madison, Wisconsin, USA); 5 ng DNA hasil isolasi dan ddH2O bebas nuklease ditambahkan agar volume reaksi mencapai $25 \mathrm{ml}$. Primer yang digunakan untuk mendeteksi gen pinII mempunyaiurutan basa forward 5'GCCTTGGGCTCATCACTCTCTCTC CTTCAC-3' dan reverse 5'- hasil foto DNA dari beberapa sampel GGAAGTTAATTTCG TTGCTTACC-3'. tanaman dapat dilihat pada Gambar 1 .

Deteksi gen pinII melalui PCR ini menggunakan mesin PCR Programable Thermal Controller (MJ Research Incorporation, Massachussetts, USA) dalam 35 siklus yang terdiri $94^{\circ} \mathrm{C}$ selama 5 menit, $94^{\circ} \mathrm{C}$ selama 1 menit, $55^{\circ} \mathrm{C}$ selama 2 menit, dan $72^{\circ} \mathrm{C}$ selama 1 menit. Hasil amplifikasi PCR kemudian diseparasi dengan $0,8 \%(\mathrm{w} / \mathrm{v})$ elektroforesis agarose gel dan pewarnaan dengan ethidium bromide (McGarvey dan Kaper, 1991; Listanto et al., 1996). Hasil PCR positif ditunjukkan dengan munculnya pita DNA pada gel hasil elektroforesis pada posisi $600 \mathrm{bp}$.

DNA total genom berhasil diisolasi dengan baik dari sampel daun tanaman kedelai transgenik R1, R2, dan non transgenik. Hal ini ditunjukkan dengan hasil kemurnian DNA yang telah memenuhi syarat, yaitu sekitar 1,5-2. Kemurnian DNA yang baik untuk uji molekuler berkisar antara 1,6-1,8. Sampel DNA murni hasil ekstraksi tersebut selanjutnya diseparasi pada gel Agarose elektroforesis $(0,8 \%)$, kemudian hasilnya difoto dengan film polaroid. Dari hasil foto gel terlihat bahwa DNA semua sampel dapat muncul/terdeteksi. Contoh 


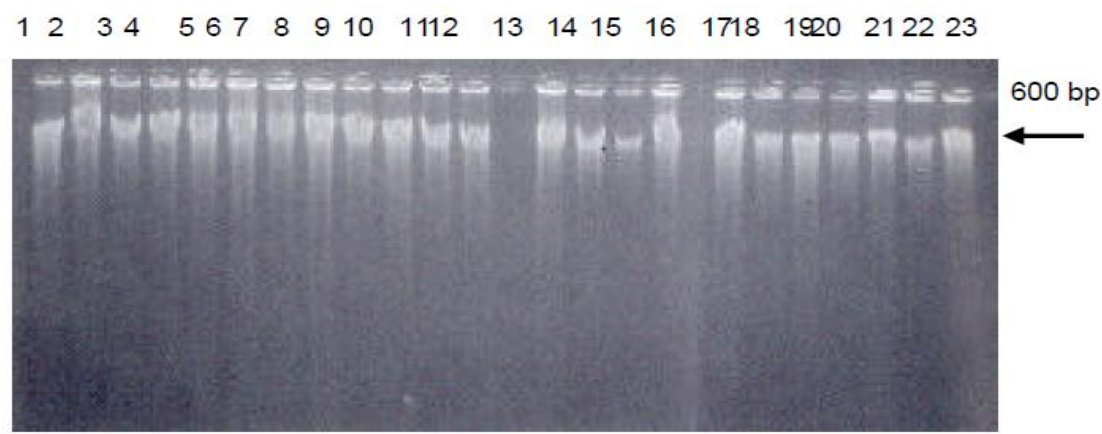

1-23 urutan sampel daun AT1-1 sampai AT1-23, tanda panah Menunjukkan posisi pita DNA sampel

Gambar 1 Foto DNA total dari sampel daun kedelai transgenik R1 event AT1(Agrobacterium) pada gel agarose $1 \%$

Sedangkan hasil isolasi DNA

seluruh sampel tanaman kedelai

transgenik disajikan pada Tabel 1.

Tabel 1 Hasil isolasi DNA total daun tanaman kedelai transgenic dan non transgenic.

\begin{tabular}{ccccc}
\hline \hline $\begin{array}{c}\text { Event } \\
\text { Tanaman }\end{array}$ & $\begin{array}{c}\text { Generasi } \\
\text { Tanaman }\end{array}$ & $\begin{array}{c}\text { Metode } \\
\text { Transformasi }\end{array}$ & $\begin{array}{c}\text { Jumlah } \\
\text { Sampel }\end{array}$ & $\begin{array}{c}\text { Hasil } \\
\text { DNA }\end{array}$ \\
\hline \hline WP2 & R1 & Penembakan & 57 & bagus \\
WP1 & R2 & Penembakan & 18 & bagus \\
TP1 & R2 & Penembakan & 9 & bagus \\
TP2 & R2 & Penembakan & 16 & bagus \\
AT1 & R1 & Agrobacterium & 27 & bagus \\
Wilis & Kontrol & Non Transformasi & 1 & bagus \\
Tidar & Kontrol & Non Transformasi & 1 & bagus \\
\hline \hline
\end{tabular}

Bagus $=$ Kemurnian DNA antara 1.5 - 2

Sampel DNA ini selanjutnya siap digunakan untuk deteksi gen pinII menggunakan teknik PCR.

\section{Kloning Gen}

Kloning merupakan salah satu langkah yang dapat digunakan untuk mengembangkan tanaman transgenik. Kloning gen bertujuan untuk memperbanyak gen interest yang diharapkan.

Sebagai contoh dalam tanaman kedelai bahwa efektivitas sistem simbiosis antara bakteri bintil akar (BBA) dengan tanaman legum sangat dipengaruhi oleh kondisi tanah. Dalam simbiosisnya dengan tanaman legum, BBA berperan untuk memfiksasi nitrogen dan 
mengubahnya menjadi amonia yang dapat digunakan oleh tanaman. Beberapa galur BBA kedelai tumbuh lambat, Bradyrhizobium japonicum, yang efektif dalam menambat nitrogen dapat memenuhi lebih kurang $74 \%$ pasokan nitrogen yang dibutuhkan tanaman kedelai tanaman kedelai (Yutono, 1985). Oleh karena itu, telaah mengenai gen yang bertanggung jawab terhadap sifat toleransi asam-Al tersebut penting diketahui untuk menelaah lebih lanjut respons fisiologi dan karakter molekuler yang berperan dalam sifat toleransi asam-Al pada $B$. japonicum.

Hasil penelitian Astuti et al., (2002) menunjukkan bahwa fragmen DNA genom sebesar $0.8 \mathrm{~kb}$ yang terlibat dalam toleran asam-Al pada B. japonicum
38 telah berhasil diisolasi dengan menggunakan teknik inverse PCR, melalui mutagenesis transposon miniTn5Km1. Fragmen DNA tersebut berhasil diklon ke dalam plasmid vector pGEMTEasy ( $3 \mathrm{~kb})$ menghasilkan plasmid rekombinan pGEMT-38 yang berukuran $3.8 \mathrm{~kb}$.

Kloning fragmen DNA genom pengapit transposon telah berhasil diligasi kedalam vektor plasmid pGEM-T Easy membentuk plasmid rekombinan pGEMT38 dan ditransformasi ke dalam sel E. coli DH5 $\alpha$. Koloni putih hasil transformasi setelah diekstrak plasmid rekombinannya, dipotong dengan EcoRI, dan dipisahkan dengan elektroforesis gel agarosa $1 \%$, hasilnya tertera pada Gambar 2.
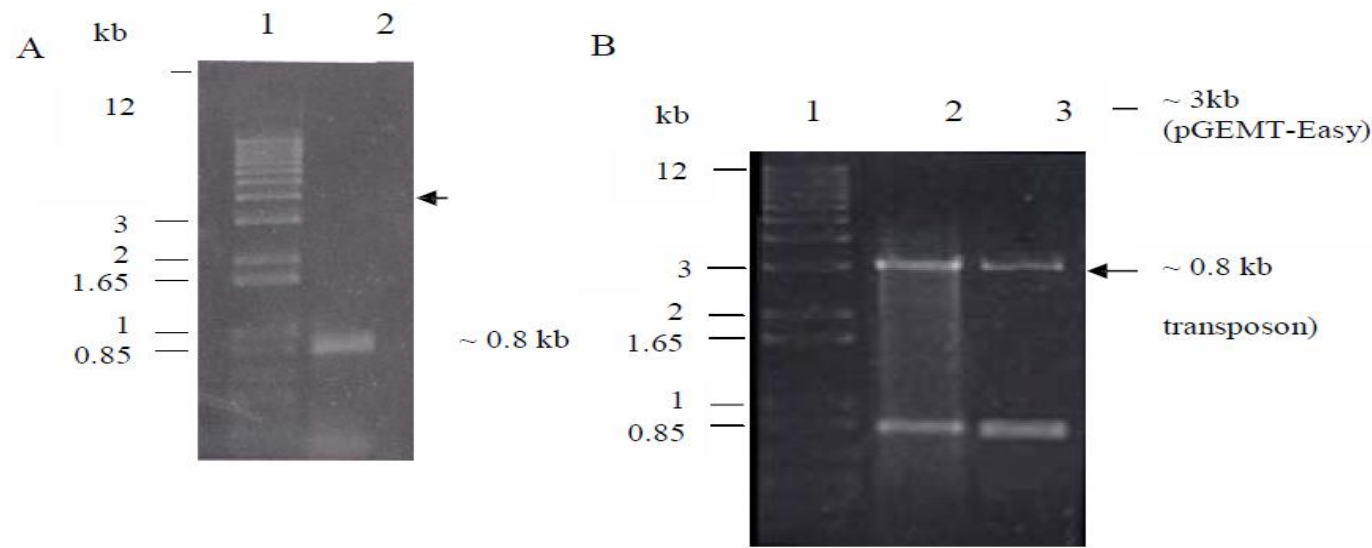

Gambar 2. A) Hasil elektroforesis gel Sumur 1: marker DNA (1 kb ladder plus), agarosa $1 \%$ dari DNA genom pengapit sumur 2: DNA hasil inverse PCR. B)Hasil transposon yang diamplifikasi dengan elektroforesis plasmid pGEMT-38 yang inverse PCR dari genom mutan AAS38. dipotong dengan enzim EcoRI.Sumur 2 
dan 3 terdapat dua pita yang berukuran $\sim 3$ menunjukkan adanya plasmid vektor $\mathrm{kb}$ (pGEMT-Easy) dan $\sim 0.8 \mathrm{~kb}$ (DNA pGEM-T ( 3 kb) dan DNA sisipan yaitu genom pengapit transposon) hasil fragmen DNA genom pengapit transposon pemotongan EcoRI. yang terlibat dalam toleransi asam-Al $(0.8$

Hasil pemotongan dengan enzim kb). Peta plasmid rekombinan pGEMT-38 EcoRI didapatkan dua pita yang $(\sim 3.8 \mathrm{~kb})$ dapat dilihat pada Gambar 3.

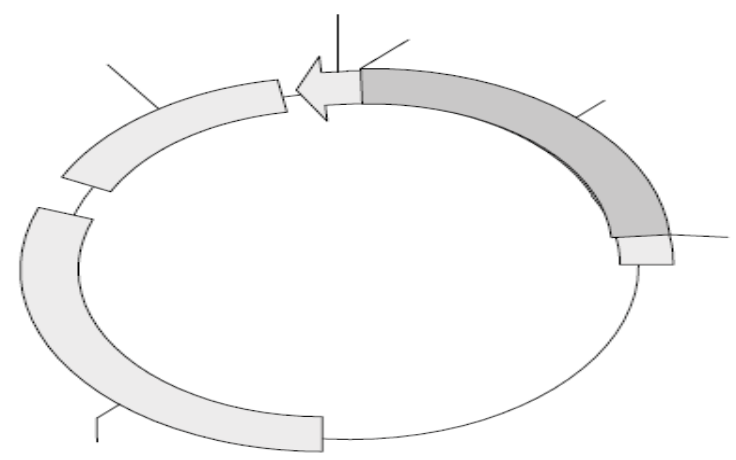

Gambar 3 Peta Plasmid rekombinan pGEMT-38 ( 3.8 kb) hasil ligasi fragmen DNA genom yang terlibat dalam toleransi asam-Al ( 0.8 kb) dengan pGEMT- Easy $(\sim 3 \mathrm{~kb})$.

Plasmid rekombinan hasil ligasi antara vektor pGEMT-Easy dengan DNA sisipan merupakan alat penting untuk telaah molekuler lebih lanjut. Plasmid rekombinan yang ditransformasi ke dalam sel E. coli DH5 $\alpha$ ini dimaksudkan untuk pembentukan klon, yaitu sel-sel individu yang mengandung molekul DNA rekombinan yang dapat dipropagasi dan disimpan untuk memproduksi molekul DNA rekombinan dalam jumlah besar sehingga dapat digunakan untuk mempelajari karakter fisiologis tertentu ataupun untuk mengkonservasi molekul DNA rekombinan dalam keadaan stabil (Dawson et al. 1996). Plasmid rekombinan ini juga dapat digunakan untuk menganalisis sekuen DNA sisipan (DNA yang terlibat dalam toleransi asamAl), sehingga dapat ditemukan sekuen homologinya dengan sekuen organisme lain pada database GeneBank. Selain itu juga dapat digunakan untuk mengetahui protein yang disandikan oleh sekuen gen tersebut dengan cara membandingkan dan mensejajarkan data urutan asam amino DNA sisipan dengan data GeneBank.

\section{Desain Gen}

Kegiatan desain gen dilakukan dengan merubah susunan basa dalam area kode (encode region) gen yang akan menentukan produksi protein tertentu 
yang diinginkan. Dalam rekombinasi DNA dilakukan pemotongan dan penyambungan DNA, melibatkan enzim tertentu. Enzim pemotong yaitu enzim restriksi endonuklease dan enzim penyambung yaitu enzim ligase. Hasil sambungan DNA dikenal sebagai DNA rekombinan. yaitu enzim ligase.

Hasil penelitian Susilawati (2013) menunjukkan bahwa penyakit hawar bakteri (bacterial blight) merupakan salah satu penyakit penting pada tanaman kedelai dan dapat menyebabkan kerugian mencapai 11-20\%. Identifikasi penyebab penyakit perlu dilakukan secara dini agar pengendalian penyakit lebih mengena sasaran. Identifikasi penyebab penyakit hawar bakteri dilakukan yaitu dengan Polymerase Chain Reaction (PCR). Pada PCR, kespesifikan primer merupakan salah satu kunci keberhasilan PCR. Patogen penyebab penyakit hawar bakteri diketahui memiliki gen spesifik yaitu gen coronafacate ligase ( $\mathrm{cfl}$ ) yang membedakannya dari spesies lain. Kekhususan gen pada bakteri target yang diidentifikasi dapat dijadikan dasar sebagai pembeda antar spesies. Penelitian ini bertujuan untuk mendesain primer yang spesifik terhadap gen $c f l$ dan mengamplifikasi sekuensi gen $c f l$ dengan
PCR menggunakan primer spesifik yang di desain.

Tahap pertama dalam desain primer dilakukan eksplorasi sekuensi gen cfl dari gen Bank NCBI dan diperoleh lima jenis bakteri dari patovar $P$. syringae dan dua jenis bakteri lain yang memiliki gen $c f l$. Perbedaan urutan sekuensi nukleotida dari masing-masing jenis bakteri selanjutnya di uji multiple alignment dengan software ClustalX, dan diperoleh lima patovar $P$. syringae yang memiliki area homologi yang tinggi. Dari lima kandidat patovar $P$. syringae yang diketahui area homologi tertinggi, selanjutnya dipilih satu sekuensi spesifik $P$. syringae pv. glycinea. Urutan nukleotida gen $c f l$ dari $P$. syringae pv. glycinea didesain primernya dengan tool bioinformatika Primer3 dan diperoleh lima kandidat primer. Lima kandidat primer tersebut di uji kembali dengan software AmplifX dan dipilih satu pasang primer yang sesuai dengan kriteria primer spesifik. Primer yang digunakan dalam amplifikasi sekuensi gen $c f l$ yaitu primer PSG_cfl2-F dengan sekuensi 5' TTCCTACGGTACGACGGAGTCT $\quad 3$ ' dan PSG_cfl2-R dengan sekuensi 3' CCCACTGGTAGTACGCAACAGA 5'. Hasil amplifikasi sekuensi gen $c f l$ 
terhadap $P$. syringae pv. glycinea dengan menggunakan primer PSG_cfl2 adalah negatif, hal ini ditunjukkan dengan ketidakmunculan pita DNA pada gel elektroforesis. Ketidakmunculan pita DNA hasil amplifikasi gen $c f l$ kemungkinan disebabkan karena bakteri target tidak memiliki gen $c f l$. Hal ini sesuai dengan temuan yang menyatakan bahwa tidak semua $P$. syringae pv. glycinea memiliki gen $c f l$. Untuk membuktikan ketiadaan gen $c f l$ pada $P$. syringae pv. glycinea maka dilakukan uji pendekatan induksi hipertropi pada jaringan kentang. Pengujian tersebut juga memberikan hasil negatif yang ditandai dengan tidak terbentuknya hipertropi pada jaringan kentang yang ditetesi dengan suspens $P$. syringae pv. glycinea. Berdasarkan pada nekrosis yang lemah pada uji virulensi dan patogenesitas, tidak terbentuknya hipertropi pada jaringan kentang dan tiadanya pita gen $c f l$ pada elektroforesis produk PCR disimpulkan bahwa $P$. syringae pv. glycinea tidak memiliki gen $c f$.

\section{Transformasi Genetika}

Transformasi genetik merupakan suatu perpindahan (transfer) gen asing yang diisolasi dari tanaman, virus, bakteri atau hewan ke dalam suatu genom baru (new genetic background) (Webb dan Morris, 1992). Beberapa teknik transformasi yang dikenal adalah elektroforesis, gene-gun dan mempergunakan bakteri Agrobakterium tumefaciens.

Penggerek polong (Etiella zinckenella Tr.) merupakan salah satu hama penting kedelai dan masih sulit dikendalikan secara konvensional. Penggunaan varietas tahan merupakan strategi terbaik dan relative aman, namun hingga saat ini sumber gen ketahanan tersebut belum ditemukan pada plasma nutfah kedelai yang ada. Perakitan tanaman kedelai transgenik tahan penggerek polong merupakan alternatif terbaik untuk mengatasi masalah ini. Metode transfer gen pada tanaman yang paling banyak digunakan adalah dengan perantara vector Agrobakterium. Karena sangat sederhana dan murah, pada prinsipnya gen interest disisipkan ke plasmid T-DNA Agrobacterium lalu diinokulasikan ke jaringan target yang telah dilukai. Namun, tidak semua jenis tanaman dapat diinfeksi oleh Agrobacterium sehingga aplikasinya terbatas pada beberapa jenis tanaman saja (Hinchee et al., 1988). 
Pardal et al., (2004) menyatakan menit dan lama kokultivasi 5 hari. bahwa transfer gen pinII pada tanaman Tanaman kedelai AT1R1 (Tidar) hasil kedelai telah berhasil dilakukan melalui $A$. transformasi melalui $A$. tumefaciens tumefaciens dengan dihasilkannya satu sedikit lebih tahan terhadap hama event tanaman AT1 (Tidar) yang penggerek polong daripada tanaman menunjukkan hasil PCR positif terhadap kedelai nontransgenik (Kontrol). gen pinII. Protokol terbaik untuk Ada pun proses transformasi transformasi kedelai melalui $A$. genetika pada tanaman kedelai dengan tumefaciens adalah menggunakana perantara bakteri A. tumefaciens secara eksplan kotiledon muda dengan kerapatan rinci disajikan pada Tabel 2.

bakteri $1 \times 10^{8} \mathrm{sel} / \mathrm{ml} /$ lama inokulasi 90

Tabel 2 Persentase gus positif pada eksplan embrio dan kotiledon muda kedelai Wilis hasil transformas dengan A. Tumefaciens

\begin{tabular}{|c|c|c|c|c|c|}
\hline \multirow{2}{*}{$\begin{array}{l}\text { Jenis eksplan/ } \\
\text { Kerapatanbakteri } \\
\text { Explan type/ } \\
\left(\mathrm{OD}_{600}\right)\end{array}$} & \multirow{2}{*}{$\begin{array}{l}\text { Jumlah } \\
\text { eksplan } \\
\text { Explant }\end{array}$} & \multicolumn{2}{|c|}{$\begin{array}{l}\text { Lama inokulasi } 60 \mathrm{menit} \\
\text { Inoculation time }(60 \mathrm{~min})\end{array}$} & \multicolumn{2}{|c|}{$\begin{array}{l}\text { Lama inokulasi } 90 \text { menit } \\
\text { Inoculation time }(90 \mathrm{~min})\end{array}$} \\
\hline & & $\begin{array}{c}3 \text { hari } \\
\text { kokultivasi }\end{array}$ & $\begin{array}{c}5 \text { hari } \\
\text { kokultivasi }\end{array}$ & 3 hari kokultivasi & 5 hari kokultivasi \\
\hline \multicolumn{6}{|l|}{ Embriomuda } \\
\hline 0.5 & 6 & $\begin{array}{c}2 \\
(33.3)\end{array}$ & $\begin{array}{c}2 \\
(33.3)\end{array}$ & $\begin{array}{c}1 \\
(16.7)\end{array}$ & $\begin{array}{c}1 \\
(16.7)\end{array}$ \\
\hline 1 & 6 & $\begin{array}{c}3 \\
(50)\end{array}$ & $\begin{array}{c}4 \\
(66.7)\end{array}$ & $\begin{array}{c}4 \\
(66.7)\end{array}$ & $\begin{array}{c}5 \\
(83.3)\end{array}$ \\
\hline 1.5 & 6 & $\begin{array}{c}0 \\
(0)\end{array}$ & $\begin{array}{c}1 \\
(16.7)\end{array}$ & $\begin{array}{c}3 \\
(50)\end{array}$ & $\begin{array}{c}1 \\
(16.7)\end{array}$ \\
\hline
\end{tabular}

Keterangan : $\mathrm{OD}_{600}=1$ setaradengan $1 \times 108 \mathrm{sel} / \mathrm{ml}$. Angkadalamkurungadalahpersentase.

Tabel 2, menunjukkan bahwa Sementara hasil transfer gen pinII eksplan embrio dan kotiledon muda kedelai sangat responsive terhadap infeksi pada eksplan kedelai melalui $A$. tumefaciens disajikan pada Tabel 3.

\section{A. tumefaciens.}


Edi Tando : Upaya Peningkatan Kualitas Tanaman Kedelai (Glycine max L. Merill) melalui Pemanfaatan Bioteknologi dalam Mengatasi Kelangkaan Pangan

Tabel 3 Hasil regenerasi dan seleksi tanaman dari eksplan kotiledon muda kedelai Wilis dan Tidar yang diinokulasi dengan A. tumefaciens yang mengandung gen pinII.

\begin{tabular}{|c|c|c|c|c|c|}
\hline $\begin{array}{l}\text { Varietas } \\
\text { varieties } \\
\end{array}$ & $\begin{array}{c}\text { Jumlaheksplan } \\
\text { Explant } \\
\text { number } \\
\end{array}$ & $\begin{array}{c}\text { Jumlahembrio } \\
\text { somatik } \\
\text { Somatic embryo } \\
\text { number } \\
\end{array}$ & $\begin{array}{c}\text { Jumlahplantet } \\
\text { Plantet } \\
\text { number } \\
\end{array}$ & $\begin{array}{c}\text { Jumlahtanaman } \\
\text { Plant number } \\
\end{array}$ & $\begin{array}{c}\text { Kodetanaman } \\
\text { Plant Code } \\
\end{array}$ \\
\hline Wilistransformasi & 1.539 & $\begin{array}{l}17 \\
1.1\end{array}$ & $\begin{array}{l}15 \\
0.9\end{array}$ & $\begin{array}{c}8 \\
0.5\end{array}$ & AW1-4 \\
\hline $\begin{array}{c}\text { Wilisnontransformasi } \\
+ \\
\text { kanamisin } 200 \mathrm{mg} / \mathrm{l}\end{array}$ & 30 & $\begin{array}{c}1 \\
3.3\end{array}$ & $\begin{array}{c}1 \\
3.3\end{array}$ & $\begin{array}{l}0 \\
0\end{array}$ & \\
\hline $\begin{array}{c}\text { Wilisnontransformasi } \\
+ \\
\text { tanpakanamisin }\end{array}$ & 30 & $\begin{array}{c}16 \\
53.3\end{array}$ & $\begin{array}{c}9 \\
30\end{array}$ & $\begin{array}{c}4 \\
13.3\end{array}$ & AW1-4 \\
\hline $\begin{array}{l}\text { Tidartransformasi } \\
\text { Tidartransformasi } \\
\text { kanamisin } 200 \mathrm{mg} / \mathrm{l}\end{array}$ & $\begin{array}{l}984 \\
30\end{array}$ & $\begin{array}{c}21 \\
2.1 \\
0 \\
0\end{array}$ & $\begin{array}{c}3 \\
0.3 \\
0 \\
0\end{array}$ & $\begin{array}{c}1 \\
0.1 \\
0 \\
0\end{array}$ & AT1 \\
\hline $\begin{array}{c}\text { Tidartransformasi } \\
\text { tanpakanamisin }\end{array}$ & 30 & $\begin{array}{l}24 \\
80 \\
\end{array}$ & $\begin{array}{c}16 \\
53.3 \\
\end{array}$ & $\begin{array}{c}6 \\
20 \\
\end{array}$ & AT1-6 \\
\hline
\end{tabular}

Tabel 3, menunjukkan bahwa varietas Wilis memberikan jumlah planlet dan tanaman yang lebih banyak (8 tanaman) dari pada Tidar yang hanya menghasilkan1 tanaman. Hal ini akhirnya hanya diperoleh satu tanaman disebabkan embrio somatik yang saja (Gambar 4). Tanaman hasil dihasilkan dari eksplan Wilis berukuran regenerasi berhasil diaklimatisasikan dan lebih besar dan bentuknya lebih sempurna sehingga mudah dikecambahkan menjadi planlet/tanaman (Gambar 2). Embrio dari eksplan Tidar, walaupun jumlahnya lebih banyak daripada Wilis, tetapi ukurannya lebih kecil dan kurang sempurna sehingga banyak yang gagal berkecambah dan tumbuh normal di rumah kaca serta menghasilkan polong yang berbiji (fertil).
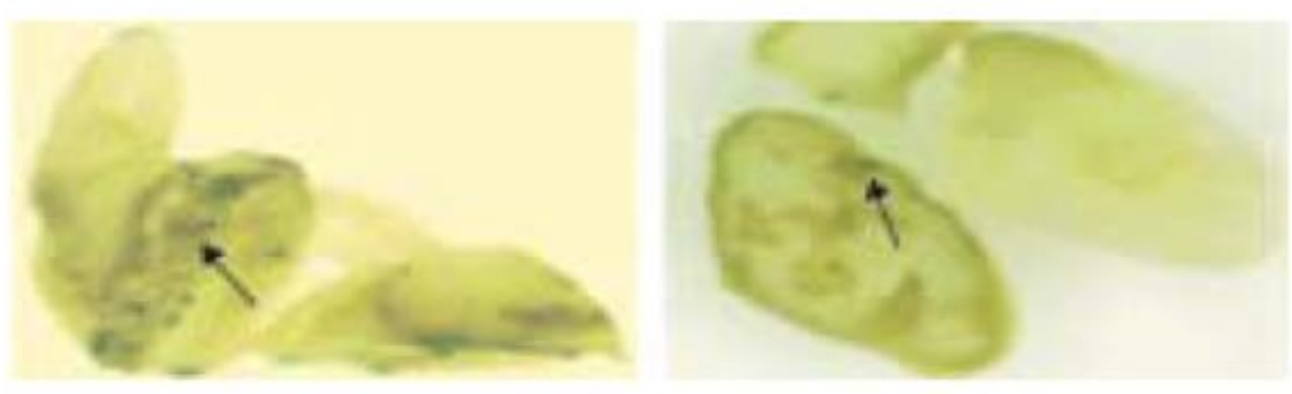

Gambar 4 Hasil uji GUS pada ekspaln kedelai hasil transformasi dengan Agrobacterium tumefaciens tampak bercak biru pada eksplan embrio (kiri) dan kotiledon muda (kanan) 

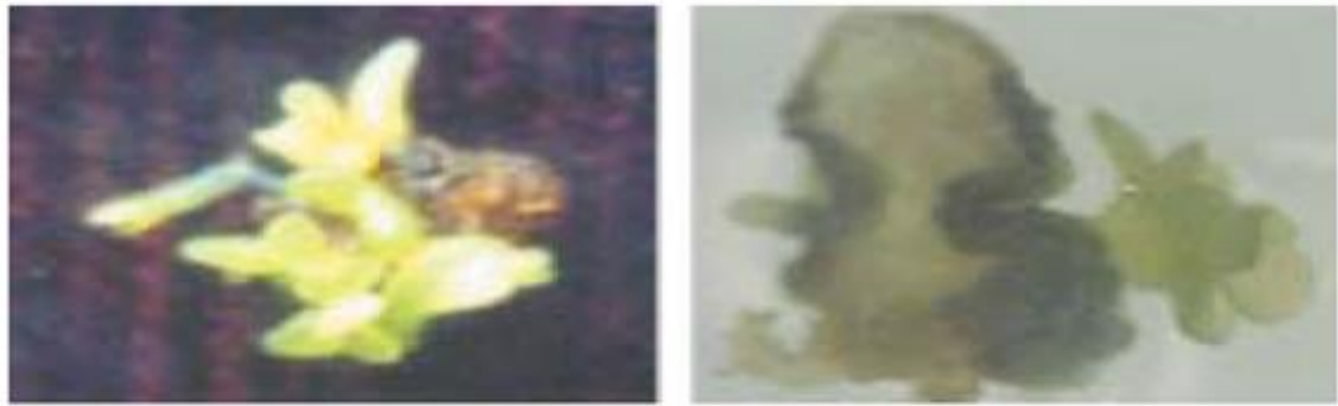

Gambar 5 Pertumbuhan embrio somatic dan eksplan kotiledon muda kedelai varietasWilis (kiri) dan Tidar (kanan) hasil transformasi melalui Agrobacterium tumefaciens pada media seleksi yang mengandungkanamisin $200 \mathrm{mg} / \mathrm{l}$
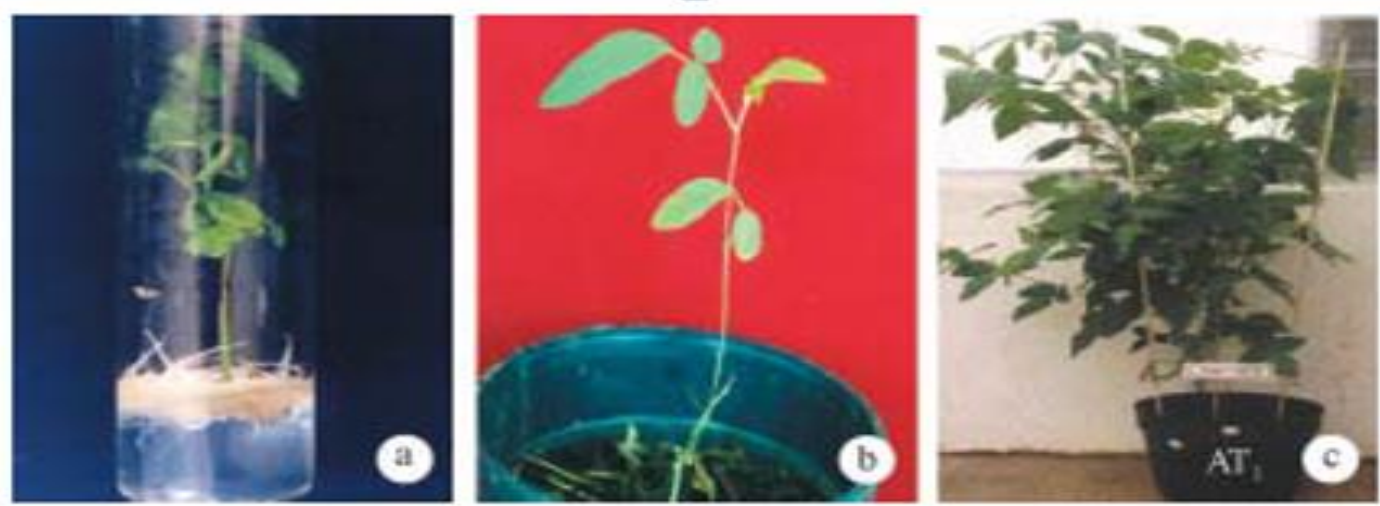

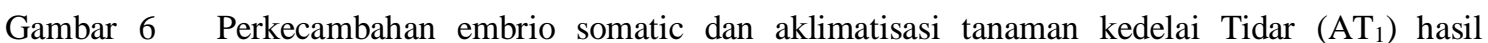
transformasi melalui Agrobacterium tumefaciens; $\mathrm{a}=$ planlet, $\mathrm{b}=$ aklimatisasi dalam pot, $\mathrm{c}$ $=$ tanaman $\mathrm{AT}_{1}$ di rumah kaca

Analisi molekuler tanaman kedelai hasil transformasi disajikan pada Gambar 7.

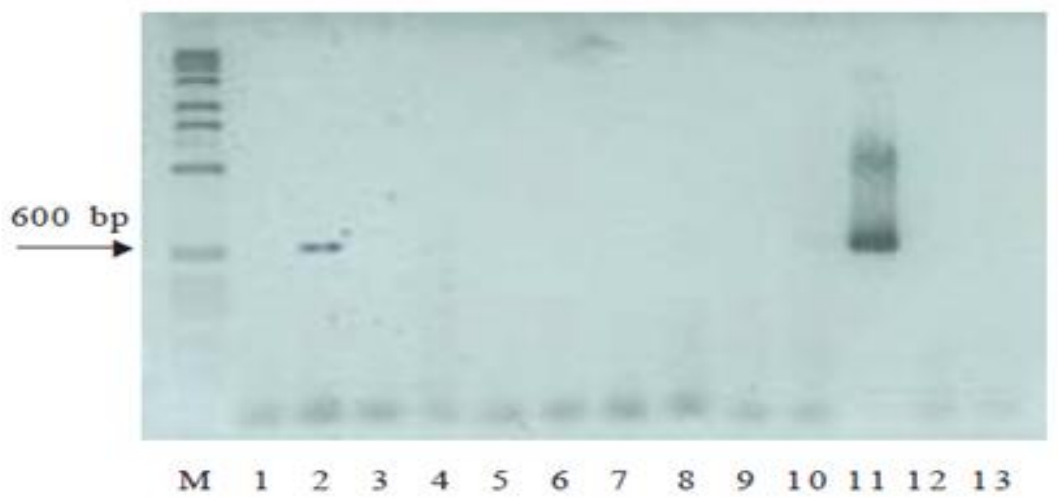

Gambar 7 Hasil PCR sampel DNA tanaman kedelai $\mathrm{R}_{0}$ hasil transformasi dengan gen pinII melaluiAgrobacterium tumefaciens; $M=1 \mathrm{~kb}, 1=\mathrm{air}, 2=\mathrm{AT}_{1}, 3-10=\mathrm{AW}_{1}-\mathrm{AW}_{8}, 11$ =gen pinII, 12 = Tidarnontransformasi, $13=$ Wilis non-transformasi. 


\section{Hasil analisis molekuler} menunjukkan bahwa hanya satu sampel tanaman yang menghasilkan pita sebesar 600 bp (positif), yaitu AT 1 (Tidar), sehingga tanaman ini kemungkinan besar mengandung gan pinII. Delapan sampel tanaman Wilis (AW1-AW8) tidak satu pun menghasilkan pita 600 bp (negatif), sehingga tanaman tersebut kemungkinan besar tidak mengandung gen pinII.

Herman et al., (2001) telah melakukan pengujian bioasai tanaman kedelai hasil transformasi terhadap larva E. zinckenella Treit. Beberapa individu yang diuji (khususnya WP1 dan AT1) memiliki ketahanan terhadap hama ini yang ditunjukkan dengan rendahnya tingkat kerusakan pada polong/biji. Biji yang sehat selanjutnya dikoleksi untuk pengujian lebih lanjut. Pada kegiatan analisis molekuler, telah berhasil diisolasi DNA total dari semua individu R1 pada semua event menggunakan sampel daun muda dengan metode modifikasi SaghaiMaroof (CTAB). DNA sampel yang telah dimurnikan selanjutnya digunakan untuk deteksi gen pinII menggunakan teknik Polymerase Chain Reaction (PCR) dengan primer spesifik untuk gen pinII. Hasil check PCR menunjukkan adanya beberapa sampel positif gen pinII, yaitu pada pita berukuran 600 bp, di antaranya AT1-7, AT1-11, AT1-21, AT1-22, AT125, dan WP2. Benih tanaman yang PCR positif akan diteruskan untuk analisis generasi berikutnya.

\section{KESIMPULAN}

1. Rekayasa genetika alternatif dalam meningkatkan kualitas tanaman kedelai dengan mengubah, memodifikasi susunan gen dengan material baru kedalam tanaman kedelai.

2. Rekayasa genetika pada tanaman kedelaimencakup : Ekstraksi DNA, Kloning gen, Desain gen, Transformasi genetika dan Pemuliaan tanamandi lapangan.

3. Ttransfer gen pinII pada tanaman kedelai telah berhasil dilakukan melaluiA. tumefaciens dengan dihasilkannya satu event tanaman AT1 (Tidar) yang menunjukkan hasil PCR positif terhadap gen pinII.

4. Protokol terbaik untuk transformasi kedelai melalui A. tumefaciens adalah menggunakana eksplan kotiledon muda dengan kerapatan bakteri 1 x $10^{8}$ sel/ml/ lama inokulasi 90 menit dan lama kokultivasi 5 hari. 
5. Tanaman kedelai AT1R1 (Tidar) hasil transformasi melalui $A$. tumefaciens sedikit lebih tahan terhadap hama penggerek polong daripada tanaman kedelai nontransgenik (Kontrol).

\section{DAFTAR PUSTAKA}

Astuti R.I. M. Dewi dan F. Sarah Asih. 2002. Kloning Fragmen DNA Genom Yang Terlibat Dalam Toleransi Asam Aluminium Pada Bradyrhizobium Japonicum. Available at : http://www.directory.umm.ac.id. 1 8.

Dawson MT, Powell R, Gannon F. 1996. Gene Technology. Graham JM, Billington D, Gilmartin PM, editor. Oxford: BIOS Scientific Publ. Ltd. $91-95$.

Fernandes, K.V.S. and J.X. Filho. 1993. Plant Molecular Biology and Genetic Engineering: Prospects for The Brazilian Northeast. R. Bras. Fisiol. Veg. (5) (2) : 187 - 191.

Hadiarto T. U. Tri Indraini R. P. Saptowo J dan M. Herman. 2002 .Analisis Molekuler Gen pinII pada Tanaman Kedelai Transgenik R2. Prosiding Seminar Hasil Penelitian Rintisan dan Bioteknologi Tanaman. 133 140.

Harsono A. 2008. Strategi Pencapaian Swasembada Kedelai melalui Perluasan Areal Tanam di Lahan Kering Masam. Iptek Tanaman Pangan Vol. 3 No. 2 : 224-257.

Herman M. S.J. Pardal. E. Listanto. T.I.R. Utami dan D. Damayanti. 2001. Evaluasi Tanaman Kedelai Generasi
R1 Hasil Transformasi dengan Gen Proteinase Inhibitor II. Prosiding Seminar Hasil Penelitian Rintisan dan Bioteknologi Tanaman. 10 - 18.

Hinchee, M.A.W. D.V. Connor Ward. C.A. Newell. R.E. Mc Donnel. S.J. Sato. C.S. Gasser. D.A. Fischoff. D.B. Re. R.T. Fraley and R.B. Horsch. 1988. Production of Transgenic Soybean Plants Using Agrobacterium Mediated DNA Transfer. Bio. Tech. (6) : 915 - 922.

Karmana I.W. 2009. AdopsiTanamanTransgenikdanBebe rapaAspekPerkembangannya.Gane $C$ Swara. (3) (2) : 12 - 21.

Listanto, E., S.J. Pardal, and Kan Wang. 1996. A Simple Method of DNA Isolation From Transgenic Maize Plant for Polymerase Chain Reaction. Indonesian Journal of Agricultural Biotechnology. (1) (1) : $33-38$.

Manuhara S.W. 2006. Pengembangan Metode Transformasi Genetik Tanaman Untuk Meningkatkan Kesejahteraan Hidup Manusia. Seminar Nasional Biodiversitas. UNAIR Surabaya. 1 - 11.

McGarvey, P. and J.M. Kaper. 1991. A Simple and Rapid Method for Screening Transgenic Plants Using the PCR. Biotechniques. (11) (4) : $428-432$.

Pardal SJ. G.A. Wattimena. A. Hajrial. M. Herman. L. Edy dan Slamet. 2004. Transfer gen proteinase inhibitor II pada Kedelai melalui vektor Agrobacterium tumefaciens untuk Ketahanan terhadap hama penggerak polong (Etiella zinckenella Tr.). Jurnal Bioteknologi Pertanian. (9) (1) $\quad: \quad 20 \quad-\quad 28$. 
Seraj, Z. I. 2001. The Exciting Future of Biotechnology. Daily Star, Edisi Selasa, 30 Januari 2001.

Sudaryanto, T. dan D.K.S. Swastika. 2007. Kedudukan Indonesia dalam perdagangan internasional kedelai. p. 28 - 44. Dalam: Sumarno et al. $(E d s$.$) . Kedelai: teknik produksi dan$ pengembangan. Puslitbang Tanaman Pangan. Bogor.

Suryanegara

I.W. 2011.

OptimismedanPesimismeRekayasaG enetika. Available at :

Susilawati R. 2013. Desain Primer Spesifik untuk Mengaplifikasi Sekuensi Gen Cfl (Coronafacate Ligase) pada Patogen Hawar Bakteri yang Menginfeksi Kedelai. Skripsi
Fakultas Pertanian Universitas Jember.

Webb, K.J. and Morris, P. (1992) Methodologies of Plant Transformation, In: Gatehouse, A.M.R., Hilder, V.A. and Boulter, D. (ed). Plant Genetic Manipulation for Crop Protection. C A B International. United Kingdom/

Yutono.1985. Inokulasi Rhizobium pada kedelai . Di dalam: Somaatmadja et al. (editor). Kedelai. Balai Penelitian dan Pengembangan Pertanian. Bogor: Puslitbangtan

Yuwono T. 2012. Bioteknologi Pertanian. Gadjah Mada University Press. Cetakan Ketiga. 1 - 284. 